\section{A validade do custeio do tratamento da infecção pelo HIV}

\section{Costs worthiness of the treatment of the HIV infection}

Ao Editor: Cada vez mais os economistas dão palpites ou até participam das decisões da área médica. Não temos nada contra que se levem em conta considerações econômicas no contexto da assistência médica e isto é obrigatório, pois diante de recursos finitos e de demandas quase que infinitas, é necessária a definição das relações custo/benefício para qualquer ato médico ou não, figurando nisto a participação dos praticantes da economia como fundamental. O que não nos parece adequado, no entanto, é atrelar decisões médicas exclusivamente a termos financeiros. Também é importante que a análise puramente econômica seja feita de maneira global. Exemplifiquemos com o tratamento dos infectados pelo vírus da imunodeficiência humana (HIV), causador da aids. Existem no Brasil entre 300.000 e 700.000 indivíduos nessa situação em, respectivamente, perspectivas otimista e pessimista. Segundo os mais modernos critérios de tratamento, quanto mais cedo ele for iniciado melhor e, nos dias que correm, a terapêutica deve ser começada sempre com pelo menos três fármacos, representados por dois inibidores da transcriptase reversa e por um da protease; contudo, determinados cientistas defendem uso precoce de quatro medicamentos anti-HIV. Uma vez iniciado o emprego torna-se preciso mantêlo durante longo período e, provavelmente, no decurso de toda a vida. Como o tratamento é efetivo, a sobrevida alonga-se e o infectado vai tomar os remédios através de durações cada vez maiores. A terapêutica não pode ser interrompida para evitar o risco de seleção de vírus resistente.

Neste país o Governo fornece os medicamentos. Um economista que só olhe as coisas pelo lado da despesa fica seriamente preocupado e com razão, porquanto a epidemia já é grande, tendendo a aumentar; assim o número de pessoas que vai precisar de medicação é progressivo. Calcula-se que no próximo ano $6 \%$ do dispêndio do Ministério da Saúde tenha vínculo com o programa de fornecimento dos antivirais e dos produtos para coibir ou prevenir infecções oportunistas das pessoas infectadas pelo HIV, sem que estejamos abrangendo todos os implicados. Gastar quase um décimo dos recursos numa única doença é assustador e, se isto aumentar, como parece inevitável, surge a pergunta: e o resto dos problemas de saúde do Brasil como é que fica? Vendo os fatos em perspectiva social e não de burocrata do Ministério da Saúde, que só pensa no gasto, o custo social do tratamento é bem menor do que parece. Pessoas que estariam sendo internadas em hospitais trabalham hoje, gerando parte do nosso Produto Interno Bruto, ou seja, sucede uma dupla vantagem, uma vez que não há dispêndio considerado grande, com o pessoal rendendo, pagando impostos e tudo o mais. Muitos dos HIV-positivos tratados jamais desenvolvem a aids e têm qualidade de vida praticamente normal, não sobrecarregando nosso precário sistema de saúde ou precisando das drogas para prevenir infecções oportunísticas. Despesas com médicos, enfermeiros e profissionais paramédicos estão sendo evitadas se ocorrer terapêutica efetiva a longo prazo, ou postergadas, configurando-se assim a melhor tradição dos políticos brasileiros, que adoram deixar para o próximo mandato os problemas que possam ser empurrados. O custo humano, envolvendo sofrimento, também diminui e, mais do que isto, cada paciente com aids clinicamente manifesta obriga um ou mais membros da sua família, quando a tem, a perder parte importante de tempo para auxiliá-lo; em outras palavras, retira tais pessoas parcial ou totalmente do mercado de trabalho.

É evidente a existência de solução que contempla todos os objetivos sociais, humanos e econômicos do problema, propiciando satisfação aos médicos, aos que acreditam na solidariedade, com necessidade de toda a sociedade auxiliar os infectados, e aos economistas mais radicais que não querem desembolsos em tratamentos, entrando em pânico em face à progressão dos gastos no futuro. Falamos da prevenção: cada caso evitado de infecção pelo HIV é uma imensa, enorme e definitiva economia. Claro que a profilaxia não vai ser bem realizada por meio de uma campanha pela televisão de vez em quando ou, então, pedindo para a população brasileira ficar casta, já que estes métodos seguramente não vêm conduzindo a sucessos. Um programa organizado de educação para a saúde, providenciado antes das primeiras relações sexuais, certamente evita muita desgraça e, mais do que isto, abranda custo que paulatinamente pode ficar insustentável. Ainda melhor, seria a disponibilidade de vacina, seguramente o mais barato de todos os recursos; não obstante, o advento de imunizante eficiente 
contra a HIV-virose parece estar ainda muito longe, porque tal peste, além de traiçoeira na invasão ao homem ainda por cima desperta resposta imune pouco valiosa, pelo menos em relação ao que conhecemos hoje. Acreditamos que ficarão resolvidas estas questões e produzida a vacina anti-HIV no próximo século, mas provavelmente não bem no começo dele.

Em que ficamos? Se pesarmos hoje custos e benefícios acreditamos que sopesando todos os fatores, o tratamento, ainda que caro, é prestimoso para a sociedade, valendo a pena manter e expandir o programa de tratamento gratuito. Não precisamos enfatizar a importância da prevenção, que não se faz apenas incentivando o uso dos preservativos masculino e feminino; a propósito, o uso deste último é estimulável e crescerá se o preço diminuir. Os remédios vão acabar ficando mais baratos, como tudo o que é produzido em larga escala pela indústria. Uma solução inadequada e desde já contestada por nós é inventar uma ilusória Remediobrás que produza os fármacos aqui, utilizando empresas farmacêuticas estatais; esta é uma fórmula segura para recriar feudos cheios de funcionários públicos com reconhecida competência em criar escritórios e coisas congêneres, mostrando-se absolutamente incapazes de aprontar algo com conotação custo/benefício efetiva.

\section{Vicente Amato Neto e Jacyr Pasternak}

Os autores são médicoinfectologistas e professores univesitários. Recebido para publicação em 28/08/98.

\section{IWHO/TDR Technical report no 811: small correction, proposal}

\author{
Relatório Técnico $n \cong 811$ da IWHO/TDR: \\ pequena correção, proposta
}

Ao Editor: A Carta ao Editor, transcrita a seguir, foi enviada ao Dr. Carlos M. Morel, Diretor da TRD - WHO, em Geneva, sugerindo pequena correção no relatório da WHO/TRD № 811.

Dear Dr. Morel:

The above mentioned technical report, wrote in 1991, constitutes one of the most important and useful documents concerning Chagas Disease Control (WHO 1991)5.

Very recently, when we were analysing an international article about the matter, a small mistake based on entomological indicators was found and the same mistake exists in the WHO document, concerning the indexes of density and crowding, as follows:

a) Density index: Number of triatomines captured/ Number of houses examined $x 100$. IT MUST BE CHANGED to: "Number of triatomines captured/ Number of houses examined";

b) Crowding index: Number of triatomines captured/ Number of houses with triatomines $x 100$. IT MUS BE CHANGED to: "Number of triatomines captured/ Number of houses with triatomines".

Comments: the mistake is the final "relativization" (percentage), since these are mere absolute correlations and not conventional indexes. In the classical Brazilian Dictionary "Aurélio", density means: 'the quality of that is dense, compact; correlation between the mass and the volume of a body. ....and, sociologically, "grade of concentration of the collective life", or "number of inhabitants of a determined area, for example, by square kilometre" 1 . In practice, the bulk we need to measure is the number of triatomines in a determined space, in order to estimate the epidemiological risk of Chagas' disease transmission. Our basic denominator (the "determined area" where density is being evaluated), in programme control, will be the unit "house", generally corresponding to different ensembles such as "localities", "municipalities", "districts", "provinces", "states" or "countries", according to the extension and/or the purpose of the measure. Multiplication for 100 does not make sense, at this time: what we need to know is "how much is the amount of existent (or collected) triatomine bugs in determined region", for instance, 3,2 bugs/ investigated house (general density data), or better, 44 bugs/positive house ("crowding data), instead of $320 \%$ (prior "density index") or $4.400 \%$ (prior "crowding index"). An important example for the comprehension of the problem can be found in the book of Angel Valencia, in Bolivia, where "Indice de densidad" is understood as "Triatomas capturados/Casas exploradas" and "indice de hacinamiento" as "Triatomas capturados/Casas com triatomas"4.

Both these mistakes apear is the page 52 of the English version of the mentioned report, and in page 55 of the Spanish version. In this last one, the name for "density index" is "índice 
de densidad", while for "crowding index" is translated as "índice de hacinamiento".

It must be remembered that both these indicators are generally considered of secondary importance and usually are not employed neither in current control programmes nor in the "Southern Cone Initiative for the Elimination of Triatoma infestans"2 6 . Nevertheless, the density of triatomines inside determined ecotopus is very important in research projects which have

1. Ferreira ABH. Novo Dicionário da Língua Portuguesa. Nova Fronteira Editora. Rio de Janeiro, 1975.

2. Fundação Nacional de Saúde. Controle da doença de Chagas. Diretrizez técnicas. Ministério da Saúde. Brasília, 1994.

3. Rabinovich JE. Ecologia poblacional de triatominos. In: Carcavallo RU, Rabinovich JE, Tonn RJ (eds) Factores biológicos y ecológicos en la enfermedad de Chagas. OPS/Ministerio de Salud y Acción Social. Buenos Aires, p. 129-147, 1985.

João Carlos Pinto Dias

Senior Researcher of FIOCRUZ

WHO Group of Parasitic Diseases the objective to measure the dynamic or the risk possibilities of $T$. cruzi transmission. Another important correlate subject concerns with the studies about insect population dynamic 3 .

We thank you very much for you attention and ask you to consider this question with Dr. Peter de Raadt, who was the chairman of the workshop which originated the document.

Yours sincerely,

4. Valencia A. Investigación Epidemiológica de la Enfermedad de Chagas. Ministerio de Previsión Social y Salud Pública. La Paz, 1990.

5. World Health Organization. Control of Chagas Disease. Report of a WHO Expert Committee. WHO Technical Report Series no 811. Geneva, 1991.

6. World Health Organization. Iniciativa Cono Sur. Informe del taller sobre definición de indicadores para la certificación de la eliminación del Triatoma infestans. PAHO/HPC/HCT/. Washington, p. 94-20, 1994.

\section{Lileia Gonçalves Diotaiuti}

Associate Researcher of FIOCRUZ

TDR Committee (AFR/Secondary Vectors)

Recebido em 14/09/98. 